\title{
Family interview for organ and tissue donation: good practice assumptions
}

\author{
Entrevista familiar para doação de órgãos e tecidos: pressupostos de uma boa prática \\ Entrevista familiar para la donación de órganos y tejidos: supuestos de buenas prácticas
}

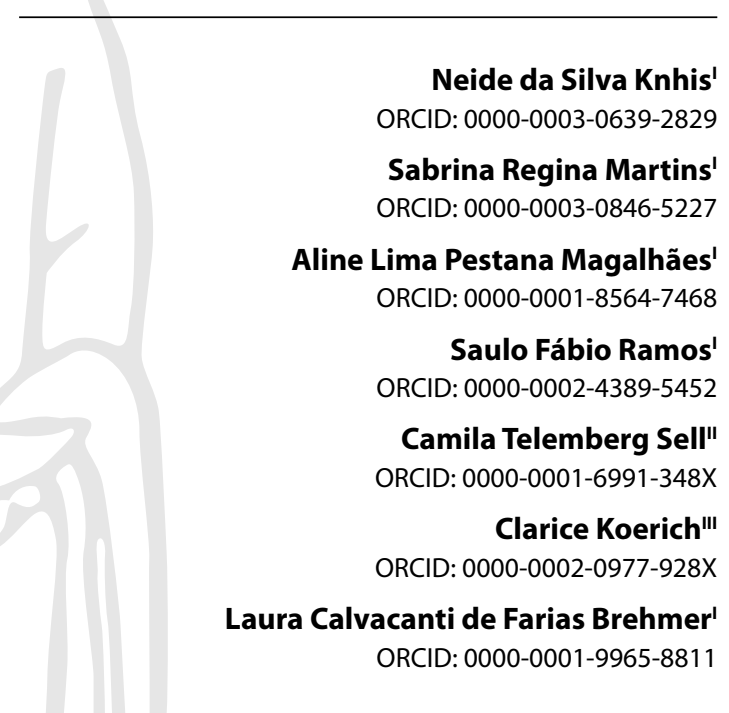

'Universidade Federal de Santa Catarina. Florianópolis, Santa Catarina, Brazil.

"Hospital Governador Celso Ramos. Florianópolis, Santa Catarina, Brazil.

I'Universidade Federal de Santa Catarina, Hospital Universitário Polyodoro Ernani de São Thiago. Florianópolis, Santa Catarina, Brazil.

How to cite this article: Knhis NS, Martins SR, Magalhães ALP, Ramos SF, Sell CT, Koerich C, et al. Family interview for organ and tissue donation: good practice assumptions.

Rev Bras Enferm. 2021;74(2):e20190206.

https://doi.org/10.1590/0034-7167-2019-0206

Corresponding author:

Sabrina Regina Martins E-mail: sabrinamartins0704@gmail.com

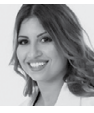

EDITOR IN CHIEF: Antonio José de Almeida Filho ASSOCIATE EDITOR: Elucir Gir

\section{ABSTRACT}

Objectives: to identify information that can support creating good practice assumptions to develop family interview for organ and tissue donation. Methods: this scoping study, conducted in two Brazilian hospitals in the southern, between April and December 2017 , included integrative review and consultation with 15 families who experienced interview for organ donation. For data analysis, thematic content analysis was used. Results: three categories emerged: communication of death, which shows the need to know the history of hospitalization of patients; emotional support, the team must have mastery of the stages of mourning; information about donation, professionals need to know the stages of the donation process and respect families' time. Final Considerations: good practice assumptions point to the need for team training, respect for family time and the use of simple language. Descriptors: Transplantation; Interview; Family; Tissue and Organ Procurement; Nursing.

\section{RESUMO}

Objetivos: identificar informações que possam subsidiar a elaboração de pressupostos de boas práticas para o desenvolvimento da entrevista familiar para doação de órgãos e tecidos. Métodos: scoping study, realizado em dois hospitais brasileiros da Região Sul, entre abril e dezembro de 2017, incluiu revisão integrativa e consulta a 15 famílias que vivenciaram a entrevista para doação de órgãos. Utilizou-se a análise de conteúdo e o modelo de entrevista familiar de Alicante para análise dos dados. Resultados: consolidaram-se três categorias: comunicação da morte, que mostra a necessidade de conhecer a história da hospitalização do paciente; apoio emocional, a equipe deve ter domínio das etapas do luto; informação sobre doação, o profissional precisa conhecer as etapas do processo de doação e respeitar o tempo da família. Considerações Finais: os pressupostos para melhores práticas apontam a necessidade de capacitação da equipe, o respeito ao tempo da família e o uso de linguagem simples.

Descritores: Transplante; Entrevista; Família; Obtenção de Tecidos Órgãos; Enfermagem.

\section{RESUMEN}

Objetivos: identificar información que pueda apoyar el desarrollo de supuestos de buenas prácticas para el desarrollo de entrevistas familiares para la donación de órganos y tejidos. Métodos: estudio de alcance, realizado en dos hospitales brasileños de la Región Sur, entre abril y diciembre de 2017, incluyó revisión integradora y consulta a 15 familias que vivieron la entrevista de donación de órganos. Para el análisis de datos se utilizó el análisis de contenido y el modelo de entrevista familiar de Alicante. Resultados: se consolidaron tres categorías: comunicación de la muerte, que muestra la necesidad de conocer la historia de la hospitalización del paciente; apoyo emocional, el equipo debe tener dominio de las etapas del duelo; información sobre la donación, el profesional necesita conocer las etapas del proceso de donación y respetar el tiempo familiar. Consideraciones Finales: los supuestos para las mejores prácticas apuntan a la necesidad de capacitación en equipo, respeto por el tiempo en familia y el uso de un lenguaje sencillo.

Descriptores: Transplante; Entrevista; Familia; Obtención de Tejidos y Órganos; Enfermería.

Submission: 06-05-2019 Approval: 12-30-2020 


\section{INTRODUCTION}

The family interview for organ and tissue donation is considered one of the most complex stages of the organ and tissue donation process. It is a meeting and/or reunion with family members of potential organ tissue donors after the death is found, which involves different stages related to communication of death, emotional support, and organ donation information ${ }^{(1-2)}$. Interview for organ donation is considered as a moment of extreme importance in the donation process and one of the most difficult for professionals, considering that, during the interview, family and professionals are vulnerable, shaken and emotionally weakened due to the loss of a family member and patients who were under their care ${ }^{(3-7)}$.

During the stages of the interview, both family and team go through unique, unique moments, which involve information about the beginning of brain death (BD) diagnostic protocol, results of clinical diagnosis tests, communication of death and possibility of organ donation ${ }^{(7-9)}$. In this painful journey, they experience the state of vulnerability inherent to the human condition, finitude. In addition to this condition, there are also other elements that can accentuate patients'vulnerability of social beings: the team, for facing professional and moral responsibility in informing about organ donation, and families, for being faced with donation decision ${ }^{(3-4,10)}$.

The vulnerable condition of these people may cause physical, emotional, social and/or spiritual suffering. Ethical, moral, religious and cultural values emerge in communication of death and information about donation by the team and family in authorizing or not organ and tissue donation of the dead family member ${ }^{(4,6-7)}$.

In Brazil, since 2001, through Law 10,211, families are legally responsible to authorize organ donation of family members after death ${ }^{(8)}$. This Law is reinforced by Decree 9,175 of 2017, describing that families have the right to be informed about the possibility of organ donation by health professionals. Furthermore, this same law determines that health teams have an obligation to inform families about the possibility of donation when death ${ }^{(9)}$ is found.

From this perspective, health teams see themselves in view of the complexity of the human dimensions of families in the mourning process, while at the same time as professional, human and ethical beings, facing the need to inform about the stages of the organ donation process in a clear, sensitive and humane way, which does not lead to suffering, doubts or confused and contradictory feelings for families. Health teams must answer all family doubts so that they can make the best decision ${ }^{(5-7)}$. Thus, it is understood that the interview requires emotional, psychological, and preparation skills from teams to recognize the stages of mourning, promote emotional support and lead the speech about organ and tissue donation ${ }^{(10-12)}$.

Literature shows that the team that monitors hospitalization, welcomes and conducts the interview for organ donation should be able to understand the dimensions of the human condition in the face of hospitalization, mourning process, donation process stages, as well as interview phases, since such situations imply a great psychological, emotional, physical, and cognitive impact ${ }^{(5-7,10-12)}$. Other studies indicate that prepared and qualified professionals make this moment welcoming and empathic with families ${ }^{(7,11-12)}$.
In this regard, the present study brings the proposal to elaborate good practice assumptions in conducting family interviews for organ and tissue donation so that professionals have support, foundation and security when welcoming families in the process of mourning and information on organ and tissue donation. Meanwhile, for families, such assumptions will provide a welcoming, humane and safe environment so that they can make this decision with greater autonomy.

Elaborating these assumptions provides health teams with a deepening of the theme, communication skills and competencies before the complexity presented in the daily work of professional activities in the process of death and dying, and in the development of interview for organ donation ${ }^{(13-14)}$. Studies indicate that in the organ and tissue donation process, guides and guidelines emerge as management tools to improve the safety and quality of procedures developed by health teams ${ }^{(15-16)}$.

When conducting the interview, the use of guidelines, guides, protocols and family interview models tend to make communication more effective, in addition to supporting health teams in the stages of this process ${ }^{(2)}$. Studies show that the effectiveness of conducting an interview for organ and tissue donation and the use of tools increase the team's confidence to act in the process and, consequently, enable credibility with families. In two other models of management tools for conducting the interview, the results show an effective communication of the professional who leads it. The articulation between team and family, in addition to reducing stress and uncertainties, also promoted reciprocity among those involved in the process ${ }^{(17-19)}$.

Given the exposed reality, it is expected that assumptions to be elaborated and presented in this study may provoke reflections, improvement and changes in the team's daily practice by conducting each stage of families interview for organ and tissue donation. Still, certainly, such a care tool will awaken an educational process in the team, contributing to the compression of the interview as a distinct and unique stage in the organ and tissue donation process. From this perspective, the main question of the study was: what information is possible to be traced through literature and with family members of possible organ donors capable of supporting the elaboration of good practice assumptions for the development of family interviews for organ and tissue donation?

\section{OBJECTIVES}

To identify information that can support creating good practice assumptions to develop family interview for organ and tissue donation.

\section{METHODS}

\section{Ethical aspects}

Considering that this research involves human beings, the project of which this manuscript is part was sent to the Research Ethics Committee of Universidade Federal de Santa Catarina. All recommendations of Resolution 466/12 of the Brazilian National Health Council (CNS - Conselho Nacional de Saúde) were followed. 
All participants signed the Informed Consent Form. Participants' anonymity was preserved by identifying the verbatins by the letter $\mathrm{F}$ followed by a number from 1 to 15, randomly chosen.

\section{Type of study}

This is a methodological study with qualitative approach, anchored by the scoping study methodological framework, developed in three moments:

First moment - literature review, which identifies evidence that can support the elaboration of assumptions through the following stages: 1) Research question identification; 2) Relevant study identification (search for studies); 3) Study selection; 4) Data extraction; 5) Data separation, summarization, and integration, and results report.

Second moment - semi-structured interview with families, represented by the sixth stage of the scoping study, called Consultation (optional)(20-21).

Third moment - preparation of assumptions considering the data obtained in previous stages. In this stage, Alicante Model for family interview was used.

\section{Methodological procedures}

The five stages proposed by the scoping study were followed, detailed below: 1) Research question identification - through an interactive process, among the researchers, following PICO strategy (P: patient, I: intervention, C: comparison, O: outcomes), where it was adapted to PIC, being " $P$ " the population (families of possible organ donors), "I" the phenomenon of interest (family interview for organ and tissue donation), and " $C$ " the context (organ donation). Thus, the main question of the study was: what information is possible to be traced through literature and with family members of possible organ donors capable of supporting the elaboration of good practice assumptions for the development of family interviews for organ and tissue donation?

In the identification of relevant studies related to the theme, second stage of the study, the following databases were considered: PubMed, Scopus, Web of Science, PsycINFO (APA), ClNAHL, LILACS, and SciELO. For the search strategy, the following descriptors were used: Brain Death; Transplantation; Obtaining Tissues and Organs; Intensive Care; Intensive Care Units; Health Personnel; Patient Care Team; Nursing; Doctors; Communication of death. Database search was carried out without restriction of publication period to cover a greater number of searches on the subject. Search syntax was developed together with a librarian.

In the third stage, each reviewer, independently and blindly, searched all databases, considering the syntaxes, reading titles and abstracts considering the inclusion and exclusion criteria. Randomized research articles, case control with population (adults or children), which presented interventions related to the stage of conducting family interview, whose outcomes showed improvements for the organ donation process were included. Articles not related to the topic, articles that did not present outcomes related to the conduct of family interview were excluded.

In the fourth stage, the organization of the information obtained in the articles selected for data collection was succeeded.
A spreadsheet was elaborated with the following information: author, year of publication, database, place of publication, population characteristic, type of study, sample size, sample calculation, development of randomization and groups, interventions performed, form of assessment of outcomes, main recommendations, and level of evidence (Level 1: obtained through meta-analysis of controlled clinical studies and with randomization; Level 2: obtained by study with experimental design; Level 3: design of almost experimental research; Level 4: emerging from delineated cohort and case-control studies; Level 5: that arise from a systematic review of descriptive and quantitative studies; Level 6: evidence derived from a single descriptive or qualitative study; Level 7: evidence from the opinions of authorities or expert committee report) ${ }^{(22)}$.

In the fifth stage, result interpretation, summarization, and dissemination, the authors elaborated data categorization based on the three phases of Alicante Model for family interview. The Alicante Model was developed in the city of Alicante, Spain, 22 years ago by professionals with expertise in communication, mourning, and organ donation, which is supported by the following references: theory of communication supported by Mauro Wolf's reflection; the aid relationship based on Carl Roger and the constructivist theory of William Worden. This model defines three steps for conducting the family interview for donation. The first stage is called communication of death; the second is called emotional support (it represents the moment after communication of death, where the professional has as main objective to help the family in the mourning process); the third represents information about organ and tissue donation ${ }^{(2,23-24)}$.

Second moment of the research: considered the sixth stage of the scoping study. This stage was developed with families who experienced family interview for organ and tissue donation.

\section{Study setting}

The research had as a setting two large hospitals in southern Brazil, which are a reference in the care of critically ill patients, besides being institutions that develop approximately forty family interviews for organ and tissue donation annually. The study was developing between April and December 2017.

\section{Survey participants}

Families who experienced interviews for organ and tissue donation in the two health institutions in the aforementioned period. Family members who participated in the organ donation interview over 18 were included. Family members who had undergone the interview less than six months ago, due to the researchers considering that the referred families are still in a very sensitive moment before the mourning process were excluded.

\section{Data collection}

To conduct data collection, participants were consulted about the possibility and interest in describing the moment when they experienced the interview for organ donation with health professionals. The interviews took place on a date 
and place predetermined by them, being conducted by two researchers. For interview development, the following question was used: how did you experience families interview for organ and tissue donation with the health team? The mean time of the interviews was 40 minutes. The interviews were recorded, transcribed and later the researchers presented the transcribed content to participants. They read and validated the content. Only after validation by participants were the information analyzed.

\section{Data organization and analysis}

Interview analysis occurred through the three stages of content analysis, as recommended by Bardin ${ }^{(25)}$ : pre-analysis, material exploration, treatment of results, inference, and interpretation. In this stage, all researchers sought to appropriate all material obtained, organizing all information, according to the interview stages of Alicante Model. In pre-analysis, text skimming was performed to formulate hypotheses that allowed the constructing of directions of analysis, considering the stages of Alicante Model. Next, the units of record were identified as well as the classification and aggregation to choose the themes.

Third moment: consolidation of information obtained through evidence (literature review) and with participants (family members) to elaborate good practice assumptions. It is notepoint that two of the researchers have extensive experience in conducting family interview, one of them with more than 16 years in practical activity of this activity, in addition to being a researcher in this theme. The elaboration of the assumptions was guided by the stages of Alicante Model for family interview (communication of death, emotional support and information on organ donation). To carry out the combination of the data of previous stages, we considered evidence, information of family members, reflection, discussion and interpretation of such data by the researchers, reaching the formation of assumptions, in order to form actions/ strategies capable of supporting health teams in all stages of conducting the interview.

For better understanding of readers, according to Alicante Model for family interview phases, the results will be presented through charts (Charts 1,2 and 3) and then the information obtained from families. This information shows findings and recommendations of the evidence and research participants who supported the elaboration of assumptions. The assumptions already consolidated will be presented below.

\section{RESULTS}

In the stage of the integrative review, 2,706 articles were identified, of these 2,552 were read the title and abstract, and 128 were read in full. After applying the inclusion and exclusion criteria considering the evaluations of the three reviewers, information was extracted from seven articles, considering evidence level 1 and 2 . Regarding the results of the second stage, contact was made with 18 families, among which 15 families participated in the study.

The following charts (Charts 1,2 and 3) and the information of participants who supported the elaboration of the assumptions will be presented, considering each stage of Alicante Model for family interview.

Corroborating the findings in literature, the data obtained from participants demonstrate how professionals communicate death. The statements indicate how vulnerable they feel before this situation, besides expressing information needs capable of promoting understanding and comfort.

Professionals should speak in a simpler way, often not we understand what they say. (F10)

When they talk about death, they need to be very clear. They should be direct, the more they are surrounding, the more shaken we become and with more difficulty understanding. (F4)

It would be interesting to talk and make room for us to ask, before starting to talk about other things. (F8)

Participants reveal feelings experienced in the mourning process, evidencing the importance of the support received by health teams, in addition to the importance of professionals recognizing these feelings.

Chart 1 - Phase 1, Alicante Model - Communication of death

\begin{tabular}{|c|c|c|}
\hline \multirow{2}{*}{ Concept* } & \multicolumn{2}{|l|}{ Evidence Integrative Review - Level of Evidence I ${ }^{(26-33)}$} \\
\hline & Factors that promote understanding about BD & Suggestions \\
\hline \multirow{8}{*}{$\begin{array}{l}\text { Represents a } \\
\text { stage in which } \\
\text { the professional } \\
\text { communicates } \\
\text { death to family } \\
\text { members in a } \\
\text { clear and simple } \\
\text { way }\end{array}$} & $\begin{array}{l}\text { Presence of a physician qualified to inform about the extreme severity } \\
\text { before starting the BD protocol; }\end{array}$ & $\begin{array}{l}\text { Do not talk about the BD protocol in the first contact with } \\
\text { families; }\end{array}$ \\
\hline & $\begin{array}{l}\text { Use of exams (tomography, imaging and others) during explanations of } \\
\text { the BD protocol; } \\
\text { Unique, sequential communication use, with the same language }\end{array}$ & $\begin{array}{l}\text { Promote the understanding of families about } \mathrm{BD} \\
\text { combined with verbal explanation with the tests } \\
\text { performed; }\end{array}$ \\
\hline & (simple language, bedside speech showing equipment); & Make up a special team with skills to assist professionals \\
\hline & Time dedication by professionals to family members, from the moment & In all stages; \\
\hline & patients enter the hospital, especially in the Intensive Care Unit; & Carry out training actions for professionals involved in \\
\hline & Specific, clear and coherent communication of the facts; & $\begin{array}{l}\text { the communication of death, as well as for professionals } \\
\text { working in a critically ill patient unit; }\end{array}$ \\
\hline & $\begin{array}{l}\text { Attention to stress, anxiety and expressions that may aggravate the fear } \\
\text { and uncertainties of families. Attention to nonverbal responses; }\end{array}$ & $\begin{array}{l}\text { Opportunistic the presence of a family member in BD } \\
\text { diagnosis; }\end{array}$ \\
\hline & $\begin{array}{l}\text { Encourage the opening to family members for visits, in relation to the } \\
\text { state to address doubts. }\end{array}$ & $\begin{array}{l}\text { Guide families before the visit in relation to patients' } \\
\text { physical state. }\end{array}$ \\
\hline
\end{tabular}

Note: BD - Brain Death; *Concepts according to Alicante Model. 
Chart 2- Phase 2, Alicante Model - Emotional Support

\begin{tabular}{|c|c|c|}
\hline \multirow{2}{*}{ Concept* } & \multicolumn{2}{|l|}{ Evidence Literature Review - Level of Evidence I I31-33) } \\
\hline & Factors that promote effective support to families & Suggestions \\
\hline $\begin{array}{l}\text { Represents } \\
\text { professional } \\
\text { support relation } \\
\text { together with } \\
\text { family in the } \\
\text { process of } \\
\text { mourning }^{(31-33)}\end{array}$ & $\begin{array}{l}\text { Attentive follow-up of the health team to family members throughout the } \\
\text { hospitalization process until the conduct of the interview; } \\
\text { Do not leave families alone, except when they verbalize this need. In the } \\
\text { absence of a qualified professional, families need other professionals who can } \\
\text { support them; } \\
\text { Welcoming and emotional care with family members throughout the process; } \\
\text { Offer psychological support to family members during the period in which } \\
\text { they await the interview stages. }\end{array}$ & $\begin{array}{l}\text { Creative, proactive training and educational } \\
\text { programs for professionals who conduct each } \\
\text { stage of the interview with family members and } \\
\text { other team professionals involved in the process; } \\
\text { Structuring the psychological support service } \\
\text { should be performed for all family members, } \\
\text { seeking to better identify feelings and how to } \\
\text { face them in the face of such a situation. }\end{array}$ \\
\hline
\end{tabular}

Note: *Concepts according to Alicante Model.

Chart 3 - Phase 3, Alicante Model - Information on organ and tissue donation

\begin{tabular}{|c|c|c|}
\hline \multirow{2}{*}{ Concept* } & \multicolumn{2}{|c|}{ Evidence Literature Review - Level of Evidence I and II (26,28,30,33-34) } \\
\hline & Essential elements of family interview & Suggestions \\
\hline $\begin{array}{l}\text { Represents the } \\
\text { phase in which } \\
\text { the health } \\
\text { professional } \\
\text { conducts the } \\
\text { donation theme } \\
\text { of organs and } \\
\text { tissues with } \\
\text { families } \\
\text { (23,25,27,30-31). }\end{array}$ & $\begin{array}{l}\text { The subject of organ and tissue donation should only } \\
\text { be inserted after understanding death; } \\
\text { Pay attention to the fact that family members of } \\
\text { children have greater difficulty assimilating death; } \\
\text { Teams should consider the time between } \\
\text { communication of death and development of donation } \\
\text { information; } \\
\text { The presence of the professional who conducted } \\
\text { emotional support at the time of the speech about } \\
\text { organ donation is important; } \\
\text { Qualification of professionals conducting family } \\
\text { interview is fundamental for the development of skills, } \\
\text { competencies, and relational techniques capable of } \\
\text { promoting self-perception and safety in the theme of } \\
\text { BD diagnosis and organ and tissue donation. }\end{array}$ & $\begin{array}{l}\text { Development of relational skills for professionals with enphase } \\
\text { in perception, understanding and empathy in relation to families } \\
\text { mourning process; } \\
\text { Professional responsible for welcoming be present and/or conduct the } \\
\text { speech about donation; } \\
\text { Individual assessment, case by case of need of time between the } \\
\text { communication of death and the talk about organ donation; } \\
\text { Development and implementation of protocols of the stages of the } \\
\text { process of reception, interview and donation of organs and tissues; } \\
\text { Consolidation of an articulated and coherent communication } \\
\text { approach among team professionals; } \\
\text { Creation of training programs with approaches that move from } \\
\text { the theoretical, technical and legal aspects of the organ and tissue } \\
\text { donation process, mourning process and conducting family interview. }\end{array}$ \\
\hline
\end{tabular}

Note: BD - Brain Death; ${ }^{*}$ Concepts according to Alicante Model.

Feeling that there is someone on our side supporting us and giving us the attention we need at this time is very important. (F13)

\section{I had a lot of support from the team, I will never forget. This was} very gratifying and made me feel safe. (F1)

Support and attention are what matters at this time, nothing else has meaning, only support. (F8)

Regarding participants' perceptions derived from the experience in the interview, controversial confrontations are observed with the recommendations pointed out by the studies.

I had a hard time understanding everything. I was very confused. They talked about death, then they've already talked about donation. That's a lot of information! I ended up not donating, because I had difficulty understanding all this. I think it would be very important to separate the speech from death and donation. (F12)

I felt a lot of pressure from the team, a lot of haste to talk about donation. They wanted an answer right away. The ideal would be to wait a little longer [...] we need time. (F5)

I had no explanation about how it occurs to the donation, I was just asked if I wanted to donate. I missed them explaining how the donation works. I wanted to donate, but I got scared. I didn't know what to say. If I had had more information, it would be better. (F15)
Phase 1

- Have a welcoming and
empathetic attitude
during the process.
- Develop
communication skills.
- Have knowledge of the
entire clinical history
of the patient since
the reception at the
institution.
- Allow family
participation in the
diagnosis of BD.
- Make room for
questions.
- Solve all family doubts.
Use clear, simple and
direct words.
terms. using technical
terms.
Recognize different
family time needs after
reporting death.

Phase 2

- Offer emotional
support by identifying
emotions and feelings
related to the stages
of grief.
- Be available to
accompany families
at all institutional
moments since the
news of the death.
Promote and
participate in training
on the process of death
and dying, help and
emotional support,
organ and tissue
donation processes.
Plan emotional support
strategies for all people
who experience grief,
including the service
staff.

Phase 3

- Compose family
interview teams only
with professionals
qualified in the
development of skills
for the entire process.
- Unlink death
communication from
information on organ
and tissue donation.
- Exercise active listening
and perception of the
appropriate time for the
interview.
- Clarify all family doubts
about the organ and
tissue donation process.
- Plan the interview
according to each case,
using strategies that do
not connote haste or
pressure for donation.
Offer the time for family
reflection and decision
making, knowing
that this time can be
variable.

Figure 1 - Good Practice Assumptions for Family Interview

Considering the findings presented and the objective of the study, Figure 1 schematically illustrates the assumptions made, which will support the health team in conducting the family interview for organ and tissue donation. Such assumptions are 
presented according to each stage of the family interview model in Alicante, Spain.

\section{DISCUSSION}

Elaborating good practice assumptions for the development of families interview for organ and tissue donation in the face of families' vulnerability in communicating death, emotional support in the mourning process and information about organ and tissue donation, present effective strategies for conducting each stage of the interview. It is considered that the knowledge obtained and presented in the assumptions harmonizes the stages of the interview, proposing resilience, humanization, welcoming, respect, valuing the human being, supporting family and team. Authors point out that, in the context of vulnerability, actions for valuing the human being, creating bonds, promoting autonomy and problem-solving strategies help and lead people to face the imposed reality ${ }^{(4,35)}$.

With regard to recommendations for good practices in communicating death, there is relevance in the assumptions regarding the need to use simple and clear language, avoiding technical terms, in addition to the space for families to ask questions, coupled with the need for team skills to address the topic of death. Such findings reveal that the team needs to be qualified, present competence and ability to communicate stages of BD diagnosis through the reality of each family, considering culture, education level, family conflicts, cognitive, emotional, and physical changes. Participants reinforce the importance of objectivity, honesty, clarity, time for assimilation and coding of what has been said for understanding. There is a lot of information from the team regarding their emotional impact, and time is an effective strategy for them to understand what was said and assimilate death.

Authors point out that at this stage of the interview, there is a need for time so that they can understand the information and accept the communication of death. These authors add that the lack of understanding of BD combined with pressure from the team to accept the news of death are the main factors that lead families to not accept organ and tissue donation ${ }^{(1,10,36)}$.

In conducting the interview, it is essential that professionals have the capacity and competence to recognize and understand whether there has been assimilation of death by families. To this end, evidence points as a key point the participation of families in all stages of BD diagnosis, in addition to alerting to verbal and non-verbal expressions emitted by them, which may indicate feelings and phases of mourning. During and after communication of death, professionals need communication skills, which are active listening, empathy and inner silence, in order to capture gestures, attitudes, emotions that express the degree of understanding and acceptance of death ${ }^{(5,26,28)}$.

Communicating death, as well as receiving news of death, is a unique, difficult and impacting moment. For families, it represents emptiness, sadness, pain, and hopelessness, in addition to other feelings. For professionals, it represents impotence, frustration and approaching their own death. Such a situation tends to be intensified when this death occurred by means of a BD, because this diagnosis is complex and involved in different stages ${ }^{(1,5,10-12)}$.

From this perspective, good practice assumptions in the second stage of the interview and emotional support bring strong welcoming and support recommendations in the elaboration of news of death as well as in each phase of mourning. Evidence, as well as participants' speeches, points to the need for time so that they can reestablish themselves from the impact of the news. In the speeches, they emphasize the importance of support and attention. Considering that this situation causes cognitive, emotional and physical changes, in addition to altering family dynamics, support is essential, in addition to respect for the time to assimilate death, appear as the right to experience pain ${ }^{(2,28,31,33)}$. In this perspective, it is understood that families' vulnerability to this reality is expressed in the biological and symbolic order of human life, with the consequent biological, existential and social fragility of these people ${ }^{(4,37)}$.

In Alicante Model, this stage appears as one of the most important in the family interview scenario. In the assumptions of this study, the findings direct emotional support for all people involved in this context, including professionals. The assumptions also emphasize the need for professionals to have competence, skills, and practice to conduct this stage, in order to offer emotional support to families, themselves and their team. In this understanding of human beings' fragility, the assumptions for better practices propose space for families to express feelings, combined with support, active listening, empathy, contributing to the process of adaptive adjustment to the situation of loss, in addition to providing a gradual reestablishment of the impact.

Regarding emotional support, studies show that professionals qualified to deal with this process and understand families' vulnerability in this scenario tend to help them move forward, improving quality of care, promoting comfort and supporting them in decisions to be taken ${ }^{(13-14,38)}$. From the perspective of this care, nurses are the leaders, due to the fact that they have a closer relationship with family members in critical patient environments, in addition to actively participating in the management and conduct of families interview for organ donation ${ }^{(3,13)}$.

Thus, it is understood that such assumptions can help teams, especially nurses, to understand the right time to conduct information on organ donation. One of the team's main difficulties in the interview is identifying the right time to introduce this topic ${ }^{(3,11,13)}$. In the present study, participants' evidence and statements made it possible to propose recommendations capable of helping the team to understand this moment. However, such findings clearly highlight the importance of knowledge, safety and ability to address the issue of organ and tissue donation. Only then, professionals will be able to perceive the ideal occasion to talk about donation. It is enough that he is attentive to verbal and non-verbal communication expressed by family members. To that end, active listening appears as one of the main recommendations. Through effective active listening, professionals will be able to capture the family's knowledge needs, while also being able to realize that they are already able to receive new information without hurry, pressure or time limitation for decision making. on organ and tissue donation. Guides, protocols and guidelines for good practices in the interview point out the time between communication of death and active listening as an essential tool to be added by health professionals. Through active listening, the professional will realize the right time to introduce the topic of organ donation ${ }^{(10-17)}$. 
Addressing the theme of organ and tissue donation is one of the most difficult moments and one of the most feared by the team. Many professionals fear to cause more pain to families, they feel as if they are attacking their vulnerability even more ${ }^{(5,11,13)}$. Such thoughts tend to generate insecurity, fear or even difficulties in talking about organ and tissue donation. This reality may be associated with little skill on the subject, lack of knowledge of current legislation, or even with the inability to deal with others' pain. These are elements that constitute barriers, which can lead families to distrust the organ donation process and culminate in the refusal to donate $\mathrm{e}^{(1,3,7,11-12)}$.

One of the recommendations of the assumptions to improve this practice at this stage of the interview is the planning of professionals'actions to conduct the interview. Planning is anchored in the sense of organizing, detailing and previously discussing strategies such as an appropriate place, time, professional who will communicate death, choice of qualified people to conduct the interview, in addition to defining family members to be present at that time. Evidence points out that interview planning minimizes team anxiety and establishes family trust with the team $^{(10-17)}$. Still in the perspective of planning, studies indicate that it is strategic that professionals are qualified in a communication course in critical situations and family interviews $s^{(5,9,23-24)}$.

The need to organize the interview is based on the importance of teams understanding that the time lived by each actor involved in this process is different. There is a chronology of time for those who receive news of death (family); there is a chronological time for those who communicate the news (team); there is a chronological time for those waiting for families' decision about donation (transplant team). Thus, understanding, respecting and paying attention to the synchrony of time is one of the great challenges of the health team, which can be improved through skills, knowledge, attitude and planning of this process.

Nurses, as protagonists and managers of the organ donation process, have the opportunity to rely on the assumptions presented here and propose changes in the practice scenario, in order to give greater visibility to their organization and performance in the context of family interview, in addition to proposing safe and effective assistance to the team through this care tool presented in this study.

\section{Study limitations}

The main limitations involve few randomized studies that point out effective strategies for conducting family interview, in addition to the difficulties in organizing dates and times for participation of all family members in information collection.

\section{Contributions to nursing, health, and public policies}

The information contained in this study offers health teams effective strategies identified through strong evidence and together with family members of patients who have undergone an interview. It is emphasized that the study shows ways of care in each stage of the interview. It stands out for nurses as managers of the organ and tissue donation process and of the interview, that the information presented allows them to manage and coordinate each phase of the interview in a distinct and clear way.

In this perspective, the findings of the study point out tactics and techniques to be developed by professionals from communication of the BD protocol stages, communication of death, emotional support and information on organ and tissue donation. Along with this, it is also pointed out that institutional and governmental managers will have opportunities to promote adjustments in public policies in order to enable greater structure in health institutions and support teams and families.

\section{FINAL CONSIDERATIONS}

The study aimed to identify information that could support the development of good practice assumptions for the development of family interviews for organ and tissue donation. During the course of the study, through the three moments and methodological guidance, strong evidence was found based on randomized studies; they emphasize the importance of simple, clear communication, with the support of trained professionals capable of promoting the understanding of $\mathrm{BD}$ diagnosis, promoting information on how organ donation develops, respecting the time between the communication of death and the speech about donation.

Still, during the methodological trajectory, the information obtained from the participants reveals the importance of clarifying the severity by all the team's professionals without being detoured. Support and attention after the news of the death, in addition to the time to assimilate the information received, are precedent and essential for an effective and safe interview, in addition to interview planning.

Based on such findings, considering the proposal to present evidence of care for best practices based on the Alicante model, the study shows feasible assumptions to be put into practice in any health institution that develops a family interview for organ donation. Such assumptions propose in each phase simple and easy actions to be performed by all health professionals. It is worth mentioning that, at each stage, the care actions emphasize the need for professionals' skills; competence to recognize and understand the families' need for their uniqueness; the importance of using communication tools; emotional support through active listening and empathy, coupled with detailed family interview planning.

It is understood that such information identified in this study, which, through the methodological sequence, allows the development of a care tool for best practices, will certainly support health teams in the development of an interview based on strong evidence, capable of promoting best practices in caring for families in this process.

\section{REFERENCES}

1. Cajado MCV. The family experience in light of the possibility of organ and tissue donation for transplantation. Rev Psicol, Divers Saúde. 2017;6(2):114-20. https://doi.org/10.17267/2317-3394rpds.v6i2.1069 
2. Gironés P, Burguete D, Machado R. Qualitative research process applied to organ donation. Transpl Proc. 2018;50(10):2992-6. https://doi. org/10.1016/j.transproceed.2018.03.012

3. Nogueira MA, Leite CRA, Reis Filho EV, Medeiros LM. Vivência das comissões intra-hospitalares de doação de órgãos/tecidos para transplante. Rev Científ Enferm. 2015;5(14):5-11. https://doi.org/10.24276/rrecien2358-3088.2015.5.14.5-11

4. Carmo ME, Guizardi FL. O conceito de vulnerabilidade e seus sentidos para as políticas públicas de saúde e assistência social. Cad Saúde Pública. 2018;34(3):e00101417. https://doi.org/10.1590/0102-311x00101417

5. Knihs NS, Leitzke T, Roza BA. Understanding the experience of family facing hospitalization, brain death, and donation interview. Ciênc Cuid Saúde. 2015;14(4):1520-7. https://doi.org/10.4025/cienccuidsaude.v14i4.26060

6. Costa CR, Costa LP, Aguiar N. The role of nursing the patient with brain death in the ICU. Rev Bioét. 2016;24(2):368-73. https://doi. org/10.1590/1983-80422016242137

7. Fonseca PIMN, Tavares CMM, Silva TN. Difficult situations management in organ donation interview. Rev Port Enferm Saúde Mental. 2016;4:69-76. https://doi.org/10.19131/rpesm.0144

8. Presidência da República (BR). Lei n 10.211 , de 23 de março de 2001. Remoção de órgãos, tecidos e partes do corpo humano para fins de transplante e tratamento [Internet]. Diário Oficial da União 23 mar 2001[cited 2017 Oct 10]. Available from: http://www.planalto.gov.br/ ccivil_03/leis/LEIS_2001/L10211.htm

9. Presidência da República (BR). Decreto n॰ 9.175, de 23 de novembro de 2017. Regulamenta a Lei n॰ 9.434, de 4 de fevereiro de 1997, para tratar da disposição de órgãos, tecidos, células e partes do corpo humano para fins de transplante e tratamento. Diário Oficial da União 23 nov 2017[cited 2017 Oct 10];240(1): 50-275. Available from: http://www.planalto.gov.br/ccivil_03/_Ato2015-2018/2017/Decreto/D9175.htm

10. Passoni R, Padilha EF, Hofstatter LM. Clinical-epidemiological elements of family interviews for donation of organs and tissues. Enferm Glob. 2017;16(2): 143-53. https://doi.org/10.6018/eglobal.16.2.234881

11. Silva Filho JB, Lopes RE, Bispo MM, Andrade AP. Nursing and family awareness in the donation of organs and tissues for transplantation: integrative review. Rev Enferm UFPE. 2016;10(Supl. 6):4902-8. https://doi.org/10.5205/reuol.8200-71830-3-SM.1006sup201624

12. Leite NF, Maranhão TLG, Farias MAA. Captação de múltiplos órgãos: os desafios do processo para os profissionais da saúde e familiares. Id on Line Rev Mult Psic. 2017;11(34):246-70. https://doi.org/10.14295/idonline.v11i34.687

13. Zanetti ML. Advanced nursing practice: strategies for training and knowledge building. Rev Latino-Am Enferm. 2015;23(5):779-80. https:// doi.org/10.1590/0104-1169.0000.2614

14. Zheng R, Lee SF, Bloomer MJ. How nurses cope with patient death: a systematic review and qualitative meta-synthesis. J Clin Nurs. 2017;27(1-2):e39-e49. https://doi.org/10.1111/jocn.13975

15. Westphal GA, Garcia VD, Souza L. Guidelines for the assessment and acceptance of potential brain-dead organ donors. Rev Bras Ter Intensiva. 2016;28(3):220-5. https://doi.org/10.5935/0103-507X.20160049

16. Magalhães ALP, Lanzoni GMM, Knihs NS. Patient safety in the process of organ and tissue donation and transplant. Cogitare Enferm. 2017;(22)2:e45621. https://doi.org/10.5380/ce.v22i1.4562

17. Weiss MJ, Hornby L, Shemie SD. Canadian Guidelines for controlled pediatric donation after circulatory determination of death: summary report. Peadiatr Crit Care Med. 2017;18(11):1035-46. https://doi.org/10.1097/PCC.0000000000001320

18. López JS, Soria-Oliver M, Aramayona B, et al. An integrated psychosocial model of relatives' decision about deceased organ donation (IMROD): joining pieces of the puzzle. Front Psychol. 2018;9:408. https://doi.org/10.3389/fpsyg.2018.00408

19. Sque $M$, Walker W, Long-Sutehall T. Bereaved donor famiies' experiences of organ and tissue donation, and perceived influences on their decision making. J Crit Care. 2018;45:82-9. https://doi.org/10.1016/j.jcrc.2018.01.002

20. Arkasey H, O'Malley L. Scoping Studies: towards a methodological framework. Int J Soc Res Methodol. 2005;8(1):19-32. https://doi. org/10.1080/1364557032000119616

21. Padilha AP, Rosa LM, Schoeller SD. Care manual for diabetic people with diabetic foot: construction by scoping study Texto Contexto Enferm. 2017;26(4):e:2190017. https://doi.org/10.1590/0104-07072017002190017

22. Galvão CM. Evidence Hierarchies. Acta Paul Enferm. 2006;19(2):5-5. https://doi.org/10.1590/s0103-21002006000200001

23. Duran BM. Modelo Espanhol é referência no mundo. Extra Classe [Internet]. 2014 [cited 2017 Oct 10];19(187). Available from: https://www. extraclasse.org.br/edicoes/2014/09/modelo-espanhol-e-referencia-no-mundo/

24. Santiago C. Donación y trasplantes de órganos e tejidos: el modelo Alicante de entrevista familiar para la donación de órganos para trasplante. Alicante[Internet]. 2016 [cited 2017 Jul 06]. Available from: http://donacion.organos.ua.es/submenu2_2/modelo_alicante.asp

25. Bardin L. Análise de conteúdo. São Paulo: Edições 70; 2011. 229p.

26. Vane DW, Sartorelli KH, Reese J. Emotional considerations and attending involvement ameliorates organ donation in brain dead pediatric trauma victims. J Trauma [Internet]. 2001 [cited 2017 Sep 08];51(2):329-31. Available from: https://insights.ovid.com/ pubmed?pmid=11493794

27. Long T, Sque $M$, Payne S. Information sharing: its impact on donor and nondonor families' experiences in the hospital. Prog Transplant. 2006;16(2):1-5. https://doi.org/10.7182/prtr.16.2.1715846273q1h784 
28. Bocci MG, D'Alo C, Inguscio S. Taking care of relationships in the intensive care unit: positive impact on family consent for organ donation. Transplant. 2016;48(10):3245-50. https://doi.org/10.1016/j.transproceed.2016.09.042

29. Tawil I, Brown LH, Comfort D. Family presence during brain death evaluation: a randomized controlled trial. Crit Care Med. 2014;42(4):93442. https://doi.org/10.1097/CCM.0000000000000102

30. Blok GA, Morton M, Morley M. Requesting organ donation: the case of self-efficacy effects of the European Donor Hospital Education Programme (EDHEP). Adv Health Sci Educ Theor Pract. 2004;9(4):261-82. https://doi.org/10.1007/s10459-004-9404-6

31. Jacoby L, Jaccardi J. Perceived support among families deciding about organ donation for their loved ones: donor vs nondonor next of skin. Am J Crit Care. 2010;19(5):52-61. https://doi.org/10.4037/ajcc2010396

32. Davel AP, Silva DR. Bereavement in the API-ES Context: aproaching narratives. Pensando Fam [Internet]. 2014 [cited 2017 Nov 10];18(1):10723. Available from: http://pepsic.bvsalud.org/pdf/penf/v18n1/v18n1a10.pdf

33. Adanir T, Erdogan I, Hunerli G. The effect of psychological support for the relatives of intensive care unit patients on cadaveric organ donation rate. Transplant Proc. 2014;46(10):3249- 52. https://doi.org/10.1016/j.transproceed.2014.05.086

34. Bellali T, Papadatou D. The decision-making process of parents regarding organ donation of their brain dead child: a Greek study. Soc Sci Med. 2007;64(2):439-50. https://doi.org/10.1016/j.socscimed.2006.09.006

35. Rosini LEA, Barros MNF. Ações preventivas no contexto da vulnerabilidade social. Serv Soc Rev. 2012;15(1):108-36. https://doi. org/10.5433/1679-4842.2012v15n1p108

36. Bonetti CE, Boes AA, Lazzari DD, Busana JA, Maestri E, Bresolini P. Organ and tissue donation and reasons for its non-realization. Rev Enferm UFPE. 2017;11(Supl.9):3533-41. https://doi.org/10.5205/reuol.10620-94529-1-SM.1109sup201705

37. Oviedo RAM, Czeresnia D. O conceito de vulnerabilidade e seu caráter biossocial. Interface. 2014;29(53):237-50. http://doi. org/10.1590/1807-57622014.0436

38. Cardoso EAO, Santos MA. Death education group: a strategy to complement undergraduate education of health professionals. Psicol Cienc Prof. 2017;37(2):500-14. http://doi.org/10.1590/1982-3703002792015 